University of Michigan Law School

University of Michigan Law School Scholarship Repository

\title{
Right of Joint Adventurers Holding All the Stock of a Corporation to a Dissolution and Accounting in Equity
}

Horace LaFayette Wilgus

University of Michigan Law School

Available at: https://repository.law.umich.edu/articles/1101

Follow this and additional works at: https://repository.law.umich.edu/articles

Part of the Business Organizations Law Commons, Securities Law Commons, and the State and Local Government Law Commons

\section{Recommended Citation}

Wilgus, Horace LaFayette. "Right of Joint Adventurers Holding All the Stock of a Corporation to a Dissolution and Accounting in Equity." Mich. L. Rev. 8 (1910): 482-4.

This Response or Comment is brought to you for free and open access by the Faculty Scholarship at University of Michigan Law School Scholarship Repository. It has been accepted for inclusion in Articles by an authorized administrator of University of Michigan Law School Scholarship Repository. For more information, please contact mlaw.repository@umich.edu. 


\section{Michigan LAW REVIEW}

POBLISHED KONTHLY DURING THE ACADEMIC YRAX, EXCLUSIVE OF OCTOBER, BY THE LAW FACULTY OF THE UHIVERSITY OF MICHICAN

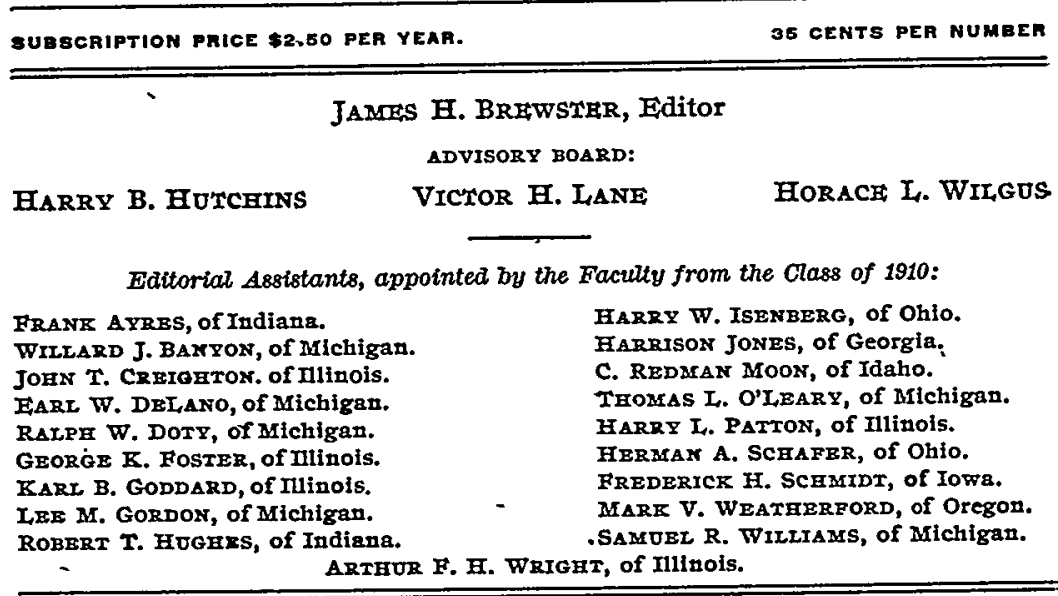

\section{NOTE AND COMMENT.}

The Right of Joint Adventurers, holding ali the Stock of a CorporaTION, TO A Dissorumion AND AccounTing in EQUiTY.-The case of Jackson v. Hooper, in the New Jersey Court of Errors and Appeals, decided February 28, Igro, by Judge Dir., (42 N. Y. Law Journal, March 8, 1910), overruling Vice Chancellor HowELI, of the Court of Chancery (74 Atl. 130) presents interesting and unusual points in corporation and partnership law, and the jurisdiction of courts of equity over corporate affairs. J. and $H$. purchased all the shares of stock in an English corporation and an Illinois corporation, under an agreement between them that they should be equal owners of the stock, and "should be partners, having equal voice and equal control in the management and business of the company; that the corporation should be treated as. a mere agency in carrying out the copartnership agreement; that the directors, other than the two parties, should be mere nominal directors; that corporateforms should be ignored and the business transacted and treated as a partnership business." The business was carried on all over the world, and with great profit for several years. The accounts were kept in a central office in London, England-the English business accounts being kept in the name of the English company, while the accounts of business in the other portions of the 
world were kept in the name of the Illinois company. Cash received, however, from any source was deposited in the same banking accounts, and payments were made from these without regard to whether they were upon English or foreign business. These deposits were subject to draft by J. and $\mathrm{H}$. individually, and each one drew indiscriminately for his private and personal use, and had drawn substantially equal amounts. No salaries were paid to either party, nor did either corporation declare dividends, nor hold shareholders' or directors' meetings for carrying on the business of either company, but all "the business" was carried on by consultation and agreement between $\mathrm{J}$. and $\mathrm{H}$. The dummy directors had little or no knowledge of, and no participation in the very large business done. Some contracts were made in the corporate names, and some otherwise. In $1908 \mathrm{~J}$. and $\mathrm{H}$. disagreed. The latter by the aid of the dummy directors took steps to exclude J. from participating in the business, in direct conflict with the agreement between them. $\mathrm{J}$., alleging that the agreement between him and $\mathrm{H}$. created a partnership, brought his bill to dissolve this, have an accounting of its affairs, restrain $\mathrm{H}$. and the directors from withdrawing the assets for private use and from excluding him from participating in the conduct of the business. The Vice Chancellor held that though the agreement did not constitute a partnership in the strict sense, yet it created a "joint adventure" between J. and $H$. over which courts of equity had jurisdiction to compel an accounting as in the case of partnerships, and that this extended to all the property (accounts receivable, cash, or copyrights) whether the title to the same was in the name of the individuals, corporations, or various trade names used by them in their business.

Judge Dili, however, ruled that a court of equity has no power to take the corporate property into its control as upon a dissolution of a partnership; the rights of the parties must be administered as shareholders in a corporation, not as partners; the agreement that certain directors should act as dummies subservient to the will of the parties, was illegal and unenforceable in equity; an injunction against the members of a board of directors individually in respect to corporate affairs is an injunction against the corporation; and a court of equity has no jurisdiction to regulate the internal affairs of foreign corporations by such an injunction.

It, of course, is elementary that a corporation, in law, is a person distinct from its members, -as for example a corporation, all the members of which are colored persons, is not itself a colored person. People's Pleasure Park Co. v. Rohleder (1908), 109 Va. 439, 615 S. E. 794 . See also 8 H. VI. I, I4 (I430); Queen v. Arnaud (I846), 25 L. J. R., part II, 50; Button v. Hoffman (1884), 6I Wis. 20; Foster and Sons v. Commrs. (1894), I Q. B. D. 516; Salomon v. Salomon, [1897] L. R. App. Cas. 22; but compare Montgomery v. Forbes (1889), 148 Mass. 249. Yet in the management of the corporation, changes in the charter, protecting corporate rights when the corporate authorities will not do so, to prevent fraud, or to punish corporate wrong-doing caused by the concerted action of shareholders, the rights or acts of the individual members, in order to prevent a failure of justice, are considered instead 
of those of a "fictitious person." Haschard v. Somany (1693), Freem. Rep. 504; Dodge v. Woolsey (1855), 59.U. S. 33I; Metcalf v. Arnold (1895), no Ala. I80; People v. North River Sug. Ref. Co. (1890), I2I N. Y. 582.

Again, courts of equity have no special jurisdiction over corporations merely as such, either to enjoin or dissolve, unless there are other sufficient reasons for going into equity. Attorney General v. Tudor Ice Co. (1870), I04 Mass. 239; Attorney-General v. Roller Skating Rink Co. (1892), I43 Ill. II8, or to appoint receivers or take the corporate property out of corporate control, Wallace v. Pierce-Wallace Co. (I897), Ior Ia. 313 .

The case of Russell v. McLellan (I833), I4 Pick (Mass.) 63, cited and relied upon by the court, was strikingly similar to the facts of this case, and was decided the same way. This case should be compared with In re Rieger, 157 Fed. 609 , referred to below. The cases of Gallagher v. Germania Brewing Co. (1893), 53 Minn. 214; Sellers v. Greer (1898), 172 Ill. 549;Nat'l Brake Beam Co. v. Equipment Co. (I907), 226 Ill. 28, 80 N. E. 556; Reinecke v. Bailey (I908), - Ky. - II2 S. W. 569 , while not the same-in facts, involved the validity and effect of agreements among shareholders concerning the corporate property and rights, and all were decided upon the theory of the case in review, and in the same way.

On the other hand, courts of equity where there seemed to be no other way of doing justice have ignored the corporate personality, and given effect to agreements existing or made among shareholders relating to the corporate property, as in Chater v. San Francisco Sugar Ref. Co. (1861), Ig Cal. 219; Bundy v. Ophir Iron Co. (I882), 38 Oh. St. 300; Home Insurance Co.v. Barber (1903), 67 Neb. 644, 60 L. R. A. 927; In re Rieger (1907), 157 Fed. 609. This last case held that the property of a corporation used as an agency of a partnership which owned 99 per cent of its stock, would be treated in equity as assets of the bankrupt partnership, and administered accordingly for the protection of creditors. And where there is an abuse of trust, a court of equity may dissolve and compel an accounting as in Miner v. Belle Isle Ice Co. (1892), 93 Mich. 97, 53 N. W. 218; see note 93 Am. St. Rep. 33. It would seem that the facts of the case under review would almost have justified a bill for the dissolution not only of the partnership but of the corporations as well, under the decision of the Miner case just cited. This, however, was not called for apparently, and there is no discussion of it, and if it was only a difference of view in regard to the management, and there was no fraud in $\mathrm{H}$. excluding $\mathrm{J}$. from the management of the business of the corporations, and the business still continued prosperous, a court of equity would not interfere. Wallace v. Pierce-Wallage Co., supra.; Fougeray v. McCord (1892), 50 N. J. Eq. 185, 756; Steruberg v. Wolff (1897-98), 56 N. J. Eq. 389, 555; Stokes v. Knickerbocker Investment Co. (1905), 70 N. J. Eq. 518.

The other points that corporations should be managed by their directors, and the courts of one state have no visitorial powers over the internal affairs of foreign corporations were decided according to the well settled rules of coroporation law. 